\title{
SISTEM PENDUKUNG KEPUTUSAN UNTUK MEMPREDIKSI JUMLAH PAKAIAN DENGAN MENGGUNAKAN METODE WEIGHT MOVING AVERAGE DAN EXPONENTIAL SMOOTHING (Studi Kasus di Toko Rookieinside Yogyakarta)
}

\author{
Eko Prasetio, Mardiana Irawaty \\ Jurusan Teknik Informatika \\ Sekolah Tinggi Teknologi Adisutjipto Yogyakarta \\ informatika@stta.ac.id
}

\begin{abstract}
Rookieinside is a store that moves in the field convection. Rookieinside had a bad in the determination of goods production which must be manufactured for sale and sometimes experience of excess supply in stock goods in the warehouse. Rookieinside requires a tool aids that can help and to maximize their performance in forecasts of work that must be manufactured so that work was not pile up in the warehouse. This application is made by using this method Weight Moving Average and Smoothing Exponential. Result of this application information about the number of record amounts that might have happened in the same will come. This application is useful to take a decision in determines the amount of work that will be produced in next period.
\end{abstract}

Keywords : Number of goods, Weight Moving Average, Exponetial Smoothing.

\section{Pendahuluan}

Rookieinside adalah merupakan toko pakaian yang memproduksi barang barang lokal seperti kemeja, kaos, celana, dan jaket. Hasil produksi ini di jual dan dipasarkan keseluruh wilayah Indonesia, oleh karena itu Rookieinside perlu melakukan suatau perencanaan strategis yang komprehenst untuk dapat menguasai pasar, salah satunya yaitu harus mampu memprediksi pola pasar yang sedang terjadi saat ini. Permasalahan yang terjadi di Rookieinside adalah ketidak tahuan seorang manager untuk menentukan jumlah pakaian yang harus diproduksi sehingga jika produksi pakaian yang diproduksi terlalu banyak maka pakaian tersebut akan menumpuk di gudang dan kerugian yang didapat akan semakin besar sedangkan jika memproduksi jumlah pakaiannya terlalu sedikit maka gudang akan kekurangan atau keuntungan nya kurang maksimal.

Metode untuk mermalkan jumlah produksi pakaian dapat dilakukan dengan cara statistika. Salah satu metode peramalan yang dapat digunakan adalah metode forecasting. Metode-metode peramalan yang dapat digunakan adalah metode Exponential Smoothing dan Weight Moving Average metode tersebut sangat cocok digunakan untuk meramalkan hal-hal yang fluktuasinya secara random atau tidak teratur.

\section{Metodologi Penelitian}

\subsection{Exponential Smoothing}

Exponential Smoothing adalah suatu tipe teknik peramalan rata-rata bergerak yang melakukan pertimbangan terhadap data masa lalu dengan cara ekponensial sehingga data 
paling akhir mempunyai bobot atau timbangan lebih besar dalam rata-rata bergerak (Murray R. Spiegel, Ph.D, 2007).

Rumus umum metode Exponential Smoothing adalah sebagai berikut

$$
S_{t+1}=\alpha X_{t}+(1-\alpha) S_{t}
$$

Keterangan :

$X_{t}$ : data asli pada periode ke-t

$S_{t}:$ nilai peramalan pada periode ke-t

$S_{t+1} \quad$ : periode peramalan (waktu hendak dilakukan peramalan)

$\alpha \quad$ : nilai perkiraan fluktuasi (diisi nilai antara $0 \mathrm{~s} / \mathrm{d} 1$ )

\subsection{Weight Moving Average}

Weight Moving Average (WMA) adalah metode moving average atau rata-rata bergerak yang memiliki bobot.Namun pada WMA terdapat bobot yang digunakan pada setiap perubahan harga. Nilai dari bobot ini dapat berapa saja dengan ketentuan nilai bobot untuk harga yang terbaru adalah lebih besar daripada nilai bobot untuk harga sebelumnya. Perumusan WMA adalah sebagai berikut:

$$
W M A=\frac{\sum(\text { data } \times \text { bobot })}{\sum \text { bobot }}
$$

Keterangan :

data : nilai penjualan.

bobot : penilaian sesuai dengan panjang periode

\subsection{Mean Absolute Deviation (MAD)}

Mean Absolute Deviation adalah nilai absolute dari penyimpangan data terhadap mean. Dengan mengetahui nilai MAD kita bisa mengetahui penyimpangan data dari rata-rata atau tingkat kesalahan peramalan menggunakan rumus sebagai berikut :

$$
M A D=\frac{\sum n}{\sum y}(\text { Nilai Forcast }- \text { Nilai Nyata })
$$

Keterangan :

n : Banyaknya bulan yang digunakan

y : Nilai penjualan

\subsection{Sistem Pendukung Keputusan}

Sistem Pendukung keputusan (SPK) adalah sebuah sistem informasi berbasis komputer yang interaktif, fleksibel yang dapat menyesuaikan diri, khususnya dibangun untuk mendukung solusi dari problem yang dihadapi sehingga menghasilkan keputusan yang terbaik (Turban, 2005).

\subsection{Perancangan Perangkat Lunak}

Sistem yang hendak dibangun adalah sistem pendukung keputusan dengan peramalan jumlah produksi barang di toko Rookieinside. Sistem tersebut harus memiliki beberapa kemampuan antara lain :

a. Menghitung jumlah penjualan dalam satu bulan.

b. Memprediksi jumlah produksi dalam tiga bulan kemudian menggunakan kedua metode tersebut untuk melakukan prediksi jumlah barang yang harus diproduksi.

c. Minimal data yang dimasukan adalah tiga bulan dan maximal data yang dimasukan adalah duabelas bulan 
d. Dalam pemberian bobot, penulis memberikan nilai yang bebas akan tetapi nilai yang diberikan pada perhitungannya yaitu sebesar satu untuk data awal atau bobot satu untuk bulan pertama dan untuk data selanjutnya bobot diharuskan lebih besar dari data pertama.

e. Membantu melakukan pengambilan keputusan tentang berapa banyak barang yang akan diproduksi.

Proses dalam sistem adalah proses peramalan. Proses ini diawali dengan menginputkan data jumlah penjualan di Rookieinside perbulan selama tiga bulan. Kemudian pengguna akan menentukan range data acuan dimasa lalu untuk melakukan peramalan. Aplikasi ini akan melakukan proses peramalan ke depan berdasarkan periode peramalan yang telah dipilih.

\subsubsection{Data Alir Diagram (DAD)}

Data Alir Diagram merupakan model proses yang digunakan untuk menggambarkan aliran data melalui sebuah sistem dan tugas atau pengolahan yang dilakukan pada system

\subsubsection{Diagram Konteks}

Diagram konteks adalah diagram tingkat atas yang hanya menggambarkan sistem secara garis besar. Merupakan diagram garis besar yang paling tidak detail dari sebuah sistem yang menggambarkan kesatuan-kesatuan luar sistem. Dari sistem yang dibuat maka akan menghasilkan diagram konteks seperti yang terlihat pada gambar 1 .

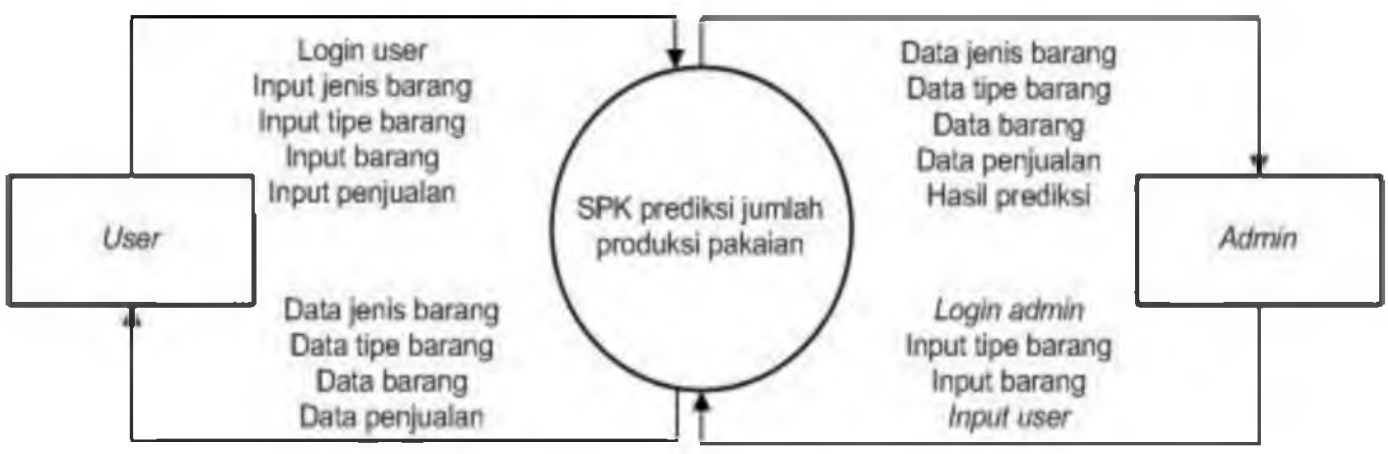

Gambar 1 Diagram Konteks

\subsubsection{Perancangan Antar Muka}

Perancangan tampilan utama aplikasi peramalan dirancang untuk memprediksi suatu jumlah pakaian yang akan diproduksi. Dapat dilihat pada gambar 2. 


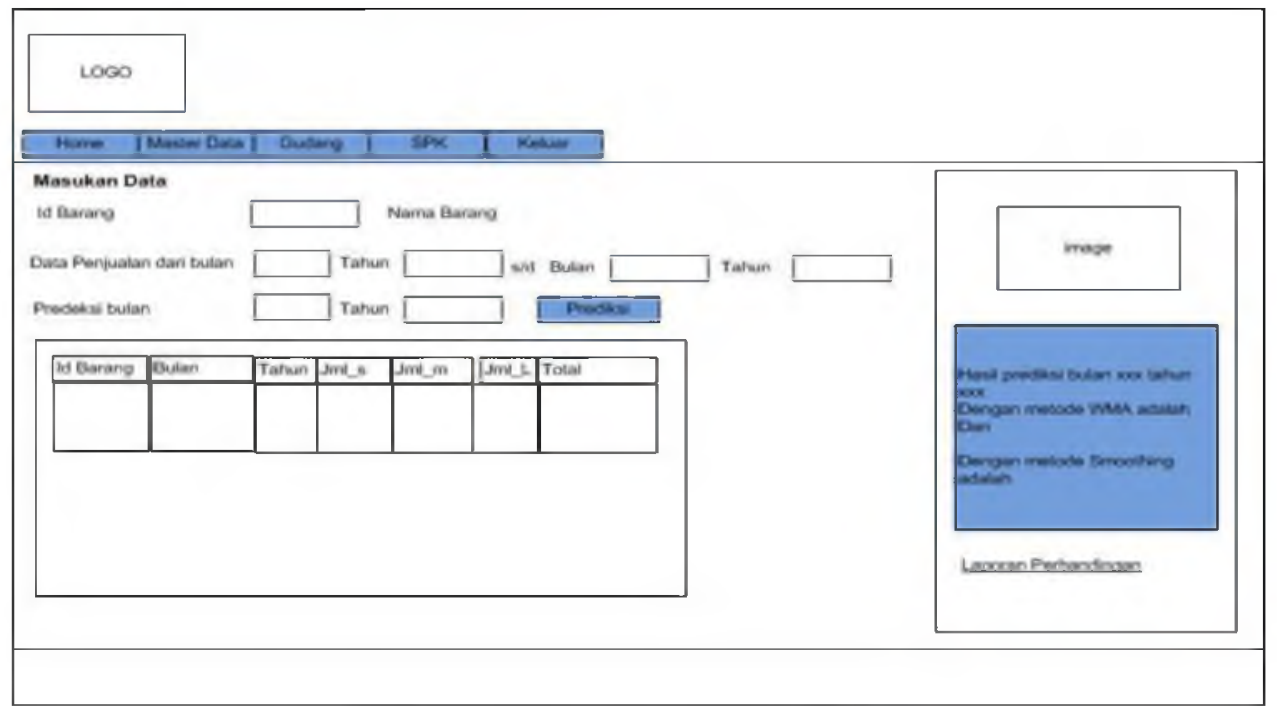

Gambar 2. Prediksi Peramalan

\section{Hasil Dan Pembahasan}

\subsection{Hasil Rancangan}

Sesuai rancangan pada gambar 2, didapat hasil penerapan aplikasi sistem pendukung keputusan seperti pada gambar 3 dan dapat dijelaskan sebagai berikut

1. Setelah program ini dijalankan dan berhasil memasukan user dan password sesuai akun yang dimilik, maka akan muncul tampilan utama aplikasi ini.

2. Langkah selanjutnya adalah memilih menu SPK maka akan tampil halaman seperti tampak pada gambar2 setelah itu masukan id barang yang akan diprediksi maka akan muncul data-data yang berkaitan dengan id barang tersebut.

3. Kemudian pilih bulan dan tahun pertama serta bulan dan tahun terakhir kemudian pilih bulan dan tahun yang akan diprediksi

4. Setelah itu tekan tombol prediksi maka data prediksi tersebut akan di tampilkan pada halaman tersebut.

5. Kemudian pilih menu laporan perbandingan untuk menentukan metode mana yang lebih baik.

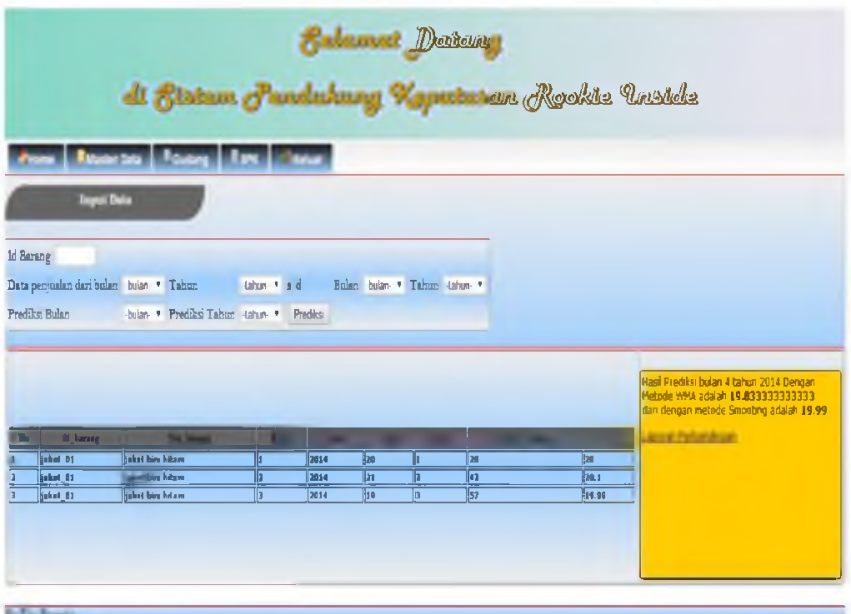

Gambar 3 Tampilan Menu Utama 


\subsection{Pembahasan}

Dari pengujian yang telah dilakukan terdapat kesamaan nilai manual dan nilai dari aplikasi sistem pendukung keputusan berikut ini adalah contoh perhitungan yang telah dilakukan pada kode barang Rock_polos01

\begin{tabular}{|c|c|c|c|c|c|c|c|}
\hline is barug & Nim barang & Bulan & Thaun & Total & Bobot & Iotal + Bobot & ST \\
\hline rock_polosol & laos polos merch & 1 & 2014 & 20 & 1 & 20 & \\
\hline rock_polos01 & kaos polos merah & 2 & 2014 & 24 & 2 & 48 & 20.4 \\
\hline rock_polosol & kaos polos merah & 3 & 2014 & 17 & 3 & 51 & 20.06 \\
\hline
\end{tabular}

Gambar 4. Hasil Exponential Smoothing pada Rock_polos01

Tabel 1.Hasil Exponential Smoothing pada Rock_Polos01.

\begin{tabular}{|c|c|c|c|c|}
\hline No & Bulan & $\begin{array}{c}\text { Jumlah } \\
\text { Penjualan }\end{array}$ & Persamaan (2.1) & $S_{t}$ \\
\hline 1 & 1 & 20 & 0.00 & 20 \\
\hline 2 & 2 & 24 & $\begin{array}{c}S_{2+1}=(0.1(24)+(1-0.1) 20) \\
S_{3}=2.4+(0.9 \times 20) \\
S_{3}=2.4+18 \\
S_{3}=20.4\end{array}$ & 20.4 \\
\hline 3 & 3 & 17 & $\begin{array}{c}S_{3+1}=(0.1(17)+(1-0.1) 20.4) \\
S_{4}=1.7+(0.9 \times 20.4) \\
S_{4}=1.7+18.36\end{array}$ & \\
& & & $S_{4}=20.06$ & 20.06 \\
\hline
\end{tabular}

Terbukti perhitungan manual dengan metode Exponential Smoothing memiliki hasil akhir yang sama dengan aplikasi untuk periode akan datang pada bulan 4 tahun 2014 dengan hasil 20.06

Sedangkan untuk mengetahui tingkat kesalahan peramalan atau standar error menggunakan persamaan (2.3)

$$
\begin{aligned}
& =\frac{3}{61}(20.06-19) \\
& =0.049 \times 1.06 \\
& =0.052
\end{aligned}
$$

Selain menggunakan metode Exponential perhitungan prediksi dihitung menggunakan metode Weight Moving Average tampak pada gambar 5. 


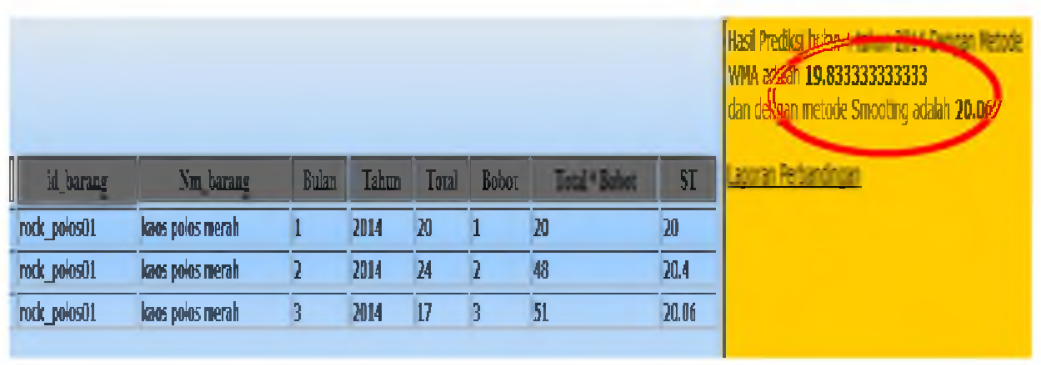

Gambar 5 Hasil Weight Moving Average

Tabel 2 HasilWeight Moving Average pada Rock_polos01

\begin{tabular}{|c|c|c|c|c|c|}
\hline No & Bulan & $\begin{array}{c}\text { Jumlah } \\
\text { Penjualan }\end{array}$ & Bobot & $\begin{array}{c}\text { Jumlah Penjualan } x \\
\text { bobot }\end{array}$ & WMA \\
\hline 1 & 1 & 20 & 1 & 20 & 48 \\
\hline 2 & 2 & 24 & 2 & 51 & $119 / 6$ \\
19.833 \\
\hline 3 & 3 & 17 & 3 & 6 & 119 \\
\hline
\end{tabular}

Terbukti perhitungan manual dengan metode Weight Moving Average memiliki hasil akhir yang sama dengan aplikasi untuk periode akan datang pada bulan 4 tahun 2014 dengan hasil 19.833. Sedangkan untuk mengetahui tingkat kesalahan peramalan atau standar error menggunakan persamaan (2.3)

$$
\begin{aligned}
& =\frac{3}{61}(19.83-19) \\
& =0.049 \times 0.83 \\
& =0.040
\end{aligned}
$$

Karena nilai Mean Absolut Deviation (MAD) atau kesalahan peramalan pada Exponential Smoothing lebih besar dari Weight Moving Average dengan demikian, peramalan untuk jumlah produksi pakaian di bulan berikutnya lebih baik menggunakan perhitungan Weight Moving Average. Pada perhitungan biaya produksi penulis mencontohkan biaya produksi pada jenis pakaian dengan kode pakaian Rock_polos01 data tersebut dapat dilihat pada tabel 3.

Tabel 3 Biaya Produksi Pada Rock_polos01 Tanpa SPK

\begin{tabular}{|l|l|l|l|}
\hline Jenis Pengeluaran & \multicolumn{1}{|c|}{ Harga Satuan } & \multicolumn{1}{|c|}{ Kuantitas } & \multicolumn{1}{c|}{ Total } \\
\hline Kaos & Rp. 55.000,- & 45 & Rp.2.475.000,- \\
\hline Design & Rp. $100.000,-$ & 1 & Rp.100.000,- \\
\hline Packaging & Rp. 5.000,- & 45 & Rp.225.000,- \\
\hline & & Total & Rp.2.800.000,- \\
\hline
\end{tabular}

Pada tabel 3 menjelaskan biaya produksi perbulan pada pakaian dengan kode Rock_polos01. Dengan jumlah biaya yang dikeluarkan dalam proses produksi sebanyak Rp.2.800.000,-. 
Tabel 4 Biaya Produksi Pada Rock_polos01 dengan SPK

\begin{tabular}{|l|l|l|l|}
\hline Jenis Pengeluaran & \multicolumn{1}{|c|}{ Harga Satuan } & \multicolumn{1}{|c|}{ Kuantitas } & \multicolumn{1}{c|}{ Total } \\
\hline Kaos & Rp. 55.000,- & 20 & Rp.1.100.000,- \\
\hline Design & Rp. $100.000,-$ & 1 & Rp.100.000,- \\
\hline Packaging & Rp. 5.000,- & 20 & Rp.100.000,- \\
\hline & & Total & Rp.1.300.000,- \\
\hline
\end{tabular}

Pada tabel 4 menerangkan bahwa biaya produksi diperoleh dari hasil aplikasi peramalan yaitu dengan hasil peramalan sebesar 20 pcs dimana total biaya produksi yang digunakan yaitu sebesar Rp.1.300.000,-

Tabel 5 Biaya Produksi Pada Rock_polos01 Hasil Penjualan

\begin{tabular}{|l|l|l|l|}
\hline Jenis Pengeluaran & \multicolumn{1}{|c|}{ Harga Satuan } & \multicolumn{1}{c|}{ Kuantitas } & \multicolumn{1}{c|}{ Total } \\
\hline Kaos & Rp. 55.000,- & 19 & Rp.1.045.000,- \\
\hline Design & Rp. $100.000^{-}-$ & 1 & Rp.100.000,- \\
\hline Packaging & Rp. $5.000,-$ & 19 & Rp.95.000,- \\
\hline & & Total & Rp.1.240.000,- \\
\hline
\end{tabular}

Pada tabel 5 menerangkan bahwa biaya produksi diperoleh dari hasil penjualan pada bulan tersebut yaitu dengan jumlah penjualan sebesar 19 pcs dimana total biaya produksi yang digunakan yaitu sebesar Rp.1.240.000,-. Dari data-data diatas maka kita akan mendapatkan perbandingan biaya yang dikeluarkan dalam memproduksi pakaian. Data tersebut dapat dilihat pada tabel 6

Tabel 6 Hasil Perbandingan Biaya Produksi.

\begin{tabular}{|c|c|c|c|}
\hline Kode Pakaian & $\begin{array}{c}\text { Biaya produksi } \\
\text { aktual setiap } \\
\text { bulan }\end{array}$ & $\begin{array}{c}\text { Biaya Produksi } \\
\text { Menggunakan } \\
\text { Aplikasi }\end{array}$ & $\begin{array}{c}\text { Biaya Produksi } \\
\text { dengan hasil } \\
\text { nyata penjualan }\end{array}$ \\
\hline Rock_polos01 & Rp.2.800.000,- & Rp.1.300.000,- & Rp.1.245.000,- \\
\hline
\end{tabular}

Dari tabel 4.17 dapat dicari nilai minimal kerugian dari produksi pakaian sebagai berikut: Kerugian biaya sebelum menggunakan aplikasi $=$ Rp. $2.800 .000-$ Rp.1.245.000 $=$ Rp. 1.555.000,-

Jadi kerugian yang didapat sebesar Rp. 1.555.000.

Kerugian biaya setelah menggunakan aplikasi $\quad=$ Rp.1.300.000 - Rp.1.245.000 $=$ Rp. 55.000 ,-

Jadi kerugian yang didapat sebesar Rp.55.000,-

Maka dari data yang telah dihitung menjelaskan bahwa biaya produksi dengan menggunakan aplikasi peramalan lebih menghemat biaya produksi yaitu sebesar Rp.55.000,lebih kecil dari biaya sebelum menggunakan aplikasi yaitu sebesar Rp.1.555.000,- sehingga dengan aplikasi peramalan, Manager bisa memaksimalkan keuntungan dan meminimalkan kerugian dari hasil produksi pakaian. 


\section{Penutup}

\subsection{Kesimpulan}

Setelah melakukan analisa, perancangan dan pengujian sistem maka dapat diperoleh kesimpulan sebagai berikut:

1. Pada hasil uji coba dapat diketahui bahwa aplikasi ini dapat membantu manager dalam menentukan berapa jumlah produksi pakaian yang optimal berdasarkan hasil prediksi yang dihasilkan dari aplikasi.

2. Diantara kedua metode yaitu Exponential Smoothing dan Weight Moving Average yang lebih baik digunakan adalah metode peramalan dengan menggunakan Weight Moving Average karena menghasilkan nilai MAD yang lebih kecil.

\subsection{Saran}

Saran yang dapat diberikan guna untuk perbaikan dan pengembangan dari aplikasi ini adalah :

1. Aplikasi ini dapat dikembangkan lagi menjadi aplikasi yang bersifat online sehingga manager perusahaan dapat mengontrol atau memprediksi tanpa ada batasan wilayah dan waktu.

2. Aplikasi ini dapat dikembangkan dengan menggunakan pemrograman berbasis android.

\section{Daftar Pustaka}

Hakim, A dan Prasetyawan, Y, 2011, Perencanaan dan Pengendalian Produksi. Penerbit Graha Ilmu, Yogyakarta.

Jogiyanto H.M., 2005, Analisis dan Desain : Pendekatan terstruktur teori dan praktik aplikasi bisnis. Penerbit ANDI, Yogykarta.

Nugroho, Adi, 2011, Perancangan Dan Implementasi Sistem Basis Data. Penerbit CV. Andi Offet, Yogyakarta.

Prasetiyo, Dwi, 2013, Sistem Pendukung Keputusan Prediksi Jumlah Penumpang Untuk Evaluasi Kapasitas Halte Bus Trans Jogja dengan Metode Exponential Smoothing (ES) dan Least Square.Jurnal Compiler, Volume 2, Nomor 1, Tahun 2013.

R.Spiegel, Murray, Ph.D dan Stephens, LJ, Ph.D, 2007, Schaums Outline Teori danSoal-soal Statistik Edisi ke-3. Erlangga, Jakarta

Subagyo, Drs. Pangestu, M.B.A. 2009, Forecasting Konsep dan Aplikasi. ISBN : 979-503-175-9

Syafii, M, 2005, Panduan Membuat Aplikasi Database dengan PHP5 My SQL, Postgre SQL, Oracle.CV Andi Offset, Yogyakarta

Turban, Efran, Aronson, Jay E, dan Peng-Liang, Ting, 2005, Decision Support System and Intelligent Systems editor by Dwi Prabantini (Sistem Pendukung Keputusan dan Sistem Cerdas). Penerbit ANDI, Yogyakarta.

Widodo, Joko, 2008, Ramalan Penjualan Sepeda Motor Honda Pada CV.RODA MITRA LESTAR.Skripsi Universitas Gunadharma Jakarta. 
PEMANFAATAN GOOGLE SPEECHPADA SMARTFHINE ANDROIDUNTUK REMUIE AFACHE WEB SERVERBERBASIS CLIENT SERVER 